\title{
LAND RESOURCE POTENTIAL AS A BASIS OF EFFICIENT USE OF LAND
}

\section{Kostyshyn Oleksandra ${ }^{1}$}

DOI: https://doi.org/10.30525/978-9934-571-89-3_132

The issue of rational use of land resource potential has been always actual. Nowadays, sustainable development is the most important and common problem. Sustainable development means achievement of a harmonious balance between

\footnotetext{
${ }^{1}$ Lviv National Agrarian University, Ukraine
} 
population, consumption and capability of land to support living. In other words, one should take from the land as much as it allows, not deteriorating and not exhausting its soil and vegetation layer and ecosystems, i.e. to use land resource potential in a rational way.

Under conditions of reforming of ownership and establishment of market relations in Ukraine, rational use of land resource potential influences structural and ecological balance of the land fund, intention of its use, reclamation of soil fertility, functioning of landscapes, and efficiency of land use in agriculture.

Land resource potential is a condition to secure sustainable development, a precondition for stable performance, a base of economic safety of a region. Under conditions of market economy development, the concepts of "potential" and "resource" are getting close in their meaning. Thus, potential of agricultural production should be considered as a complex of land resources, necessary for their performance and development. Land resources make a territorial basis for social production, improve and increase their productivity due to efficient use. It is also effective to use land in the way, which secures scientifically argued economic effect of farming and improves soil fertility and ecological conditions of the environment. Moreover, a complex of organizational and economic measures is focused on protection and reclamation of soil fertility, ecological balance of landscapes, improvement of other useful properties of land and environment [3].

Lviv region is an area, which has potentially effective land resources. Total area of the region constitutes 2183197,4 ha, including 1292655,3 ha of agricultural land, i.e. $59,2 \%$ of the total area. At the current stage of establishment of the regional economy, an important step is to determine indicators of economic potential of land resources of regions. On the other hand, economic potential immediately depends on development and structure of agricultural branch of production on some territory. Efficiency of the resource potential use is a proportion of the obtained results of production and the employed resources. A maximum of the obtained results at minimum costs is considered the criterion of efficiency. Growth of gross output is a principal indicator in assessment of land resources use.

Principal indicators for assessment of the efficiency of economic potential of land resources on the territory of a region include a level of security of the national economy with agricultural products, population with food products, industry with raw materials, and trade with food products. Economic indicators are a concentrated expression of quality and quantity transformations in agrarian economy. Their values are changed depending on development of agrarian production and depict its objectivity and expectancy [2]. Level of agricultural production is mainly influenced by the land content. However, efficiency of land use is influenced by many factors, particularly level of productive forces development, degree of land plowing, structure of cropping area, share of drained land in the total area of agricultural lands and, to some extent, by legal status of lands, i.e. a form of ownership. Rise of the efficiency of land resources use is one of the most important problems of the national economy. Successful solution of the problem can contribute to efficient performance of agricultural enterprises. 
Rational and efficient use of land by agricultural enterprises can be supplied by taking measures concerning improvement of soil fertility, protection from erosion and other destructive processes. Considering national interests, society should employ land so it can stay improved for the future generations. Introduction of the achievements of scientific and technical progress and intensive technologies in agriculture objectively requires consideration of not only their positive impact on land, but possible negative effects, caused by specific impacts of some production means. Thus, one can distinguish the following main directions for improvement of the economic efficiency of land use in agriculture:

1) a system of measures concerning improvement of land fertility;

2) protection of soil from erosion and other destructive processes;

3) reduction of the area of land, intended for conservation and layland. Economic efficiency of production resource use in crop production substantially depends on the level of soil fertility. Dynamics of the content of humus in the soils of different zones of Ukraine confirms that growing of high yields of agricultural crops, under conditions of a deficit-free balance of humus, requires increased application of organic fertilizers. It is necessary to apply 10,5 ton of organic fertilizers per 1 hectare of arable lands, including 14 ton - on Polissia area, 11 ton - in Forest Steppe, 9 ton in Steppe. Diversity of natural conditions causes the necessity to introduce a scientifically argued system of agricultural farming, which expects increase of soil fertility, improvement of agricultural land quality. Thus, the system of arable farming is a key constituent of the system of agricultural production. It secures an optimal use of land resources in terms of complex interdependent agro-technical, reclamation and organizational-economic measures, focused on efficient use of land, protection and increase of soil fertility, obtaining of high yields of agricultural crops. The system of arable farming should make structuring of cropping areas, determine the system of crop rotation, soil treatment, fertilization, seed production, measures of fight against weeds, pests and diseases of agricultural crops, system of reclamation measures, soil protection from water and wind erosion, environmental protection. Farms should increase the number of soil-protective measures and methods of land tillage, as well as anti-erosion measures. Landowners and land users have to take measures of soil protection from wind and water erosion, prevent salinization, swamping, and weed growing, as well as other processes, which deteriorate soil conditions.

A complex system of land protection expects introduction of soil-protective crop rotation, subsurface soil treatment, soil-protective technologies of agricultural crops growing, field-protective forests and other anti-erosion measures. A soil-protective plowless system of arable farming should secure intensification of crop production branches, reclamation and improvement of soil fertility. Such measures will contribute to increase of yield of agricultural crops, reduction of labor consumption and costs per a unit of products. Introduction of soil-protective systems of arable farming stimulates reduction of erosion-dangerous areas of soil, because annually, the area of arable lands is sufficiently reduced in Ukraine due to increase of ravines, while erosion processes cause loss of 3,5 million ton of mineral fertilizers (calculated as $100 \%$ of nutrients) at fields and pastures. 
Thus, the concept of "land resource potential" is characterized by an aggregate of resources of a land area, which determine ecological conditions of life and settling of people, are used for placing of production means and have biological productivity for economic activity. "Its rational use" expects a triunity of a harmonious combination of ecological, economic and social directions.

\section{References:}

1. Dobriak D.S., Tykhonov A.H., Palamarchuk L.V. (2004). Economic turnover of land in Ukraine: theory, methodology and practice. Kyiv: Urozhai.

2. Ivanukh R.A., Dusanovskyi S.L., Bilan Ye.M. (2003). Agrarian economy and market. Ternopil: Zbruch.

3. Marmul L.O., Romanova V.A. (2007). Regional management and regulation of land resources use: monograph. Kyiv: ESC IAE.

4. Dankevych Y. Dankevych V., Chaikin O. (2016). Ecologically certified agricultural production management system development. Agricultural and Resource Economics : International Scientific Journal, vol. 2, no. 4, pp. 5-16. Mode of access: https://www.arejournal.com.

5. Dziadykevych Yu.V. (Eds.). (2016). Ekonomika dovkillia i pryrodnykh resursiv: monohrafiia [Economics of the environment and natural resources]. Ternopil, Aston. (in Ukrainian) 